\title{
Nilai-Nilai Pendidikan Akhlak Dalam Kitab Risalatul Mu'awanah Dan Relevansinya
}

\author{
Muhammad Syamsi Harimulyo, Benny Prasetiya, Devy Habibi Muhammad \\ STAI Muhammadiyah Probolinggo \\ E-mail : *hasbulamin208@gmail.com, prasetiyabenny@gmail.com, hbbmuch@gmail.com
}

Diterima: Desember 2020 ; Dipublikasikan Januari 2021

\begin{abstract}
ABSTRAK
Pendidikan akhlak merupakan upaya sadar yang bertujuan untuk menanamkan rasa percaya diri dalam hati untuk mencapai perilaku terarah yang baik dan menjadikannya sebagai kebiasaan. Merosotnya nilai moral atau moral degeneration yang sudah banyak terjadi pada zaman ini, salah satu penyebabnya adalah keyakinan atau iman yang lemah. Penelitian ini bertujuan untuk: (1) mengetahui nilai pendidikan akhlak dalam kitab Risalatul Mu'awanah. (2) mengetahui Relevansi kitab Risalatul Mu'awanah terhadap pendidikan terutama anak didik pada saat ini. Untuk mencapai tujuan di atas, maka digunakanlah metode kepustakaan. Pengumpulan data pada penelitian ini dilaksanakan melalui metode pencatatan. Metode analisis data dalam penelitian ini adalah metode analisis deskriptif, serta berusaha menganalisis dan menjelaskan data. Hasil penelitian tentang nilai-nilai pendidikan akhlak dalam kitab Risalatul Mu'awanah dan Relevansinya antara lain (1) Nilai-nilai Pendidikan Akhlak yang terdapat pada Kitab Risalatul Mu'awanah di golongkan menjadi dua kategori yakni Nilai Ilahiyah dan Nilai Insaniyah (2) Implementasi Nilai-nilai Pendidikan Akhlak yang ada pada kitab Risalatul Mu'awanah karangan Al-Habib Abdullah Al-Haddad dapat dilaksanakan oleh anak didik dengan pelaksanaan-pelaksanaan berbagai bahasan seperti cinta kepada Allah SWT, rela atau ridho dengan ketentuan atau Taqdir Allah, memperkuat keimanan atau keyakinan pada diri, memperbaiki atau meluruskan niat, mengisi waktu dengan melaksanakan berbagai hal yang bermanfaat, akhlak atau adab dalam Melakukan kegiatan sehari-hari, menjaga tulusnya hati, selalu kembali atau bertaubat pada Allah swt, bersikap shabar, menjaga kebersihan lahiriyah maupun bathiniyah, berbakti kepada kedua orang tua, berbicara baik dengan sesama, Amar ma'ruf dan nahi munkar, menghindari candaan yang berlebihan, memuliakan atau ta'dhim pada guru, saling tolong menolong, bersikap ramah kepada sesama dan menjaga silaturrahmi terhadap kerabat dan tetangga, Pendidikan agar selalu memiliki sifat simpati kepada orang lain.
\end{abstract}

Kata Kunci: Kitab Risalatul Mu'awanah, Pendidikan Akhlak

\section{ABSTRACT}

Moral education is a conscious effort that aims to instill self-confidence in the heart to achieve good directed behavior and make it a habit. The decline in moral values or moral degeneration that has occurred in this era, one of the causes is a weak belief or faith. This study aims to: (1) determine the value of moral education in the Risalatul Mu'awanah book. (2) knowing the relevance of the Risalatul Mu'awanah book to education, especially students at this time. To achieve the above objectives, the library method is used. Data collection in this study was carried out through the recording method. The data analysis method in this research is descriptive analysis method, and tries to analyze and explain the data. The results of research on the values of moral education in the Risalatul Mu'awanah book and their relevance include (1) Moral Education values contained in the Risalatul Mu'awanah Book are classified into two categories namely Divine Values and Insaniyah Values (2) Value Implementation Moral Education values contained in the Risalatul Mu'awanah book written by Al-Habib Abdullah Al-Haddad can be carried out by students by implementing various topics such as love for Allah SWT, being willing or pleased with the provisions or God's destiny, strengthening faith or belief self, correcting or straightening intentions, filling time by carrying out various useful things, morals or etiquette in carrying out daily activities, maintaining a sincere heart, always returning or repenting to Allah swt, being patient, maintaining physical and spiritual cleanliness, being devoted to both parents, talk well to each other, Amar ma'ruf and nahi munkar, avoid ca excessive demands, glorifying or ta'dhim on teachers, helping each other, being friendly to others and maintaining friendship with relatives and neighbors, Education to always have sympathy for others.

Keywords: Book of Risalatul Mu'awanah, Moral Education Pendidikan 


\section{PENDAHULUAN}

Pendidikan memiliki pera yang signifikan dalam membangun masyarakat yang bermoral (Idi \& Sahrodi, 2017; Devy, 2020). Dalam mendefinisikan pendidikan, para ahli mempunyai banyak pandangan, terkadang tidak saja dilihat dari sisi redaksi bahkan pada sisi substansi. Dalam membangun suatu budaya, pendidikan kepribadian memiliki pengaruh yang signifikan pada peradaban manusia. (Arif, 2018)

Mungkin tidak banyak yang menyadari bahwa sistem pendidikan di indonesia ini sebenarnya hanya untuk mereka yang memang memiliki bakat pada potensi akademik (ukuran IQ) tinggi saja atau hanya menyiapkan para anak didiknya untuk memasuki jenjang perguruan tinggi. (Avinesa, 2018)

Pendidikan adalah sebuah proses menanamkan kelimuan pada anak didik atau siswa . Namun yang ditanamkan oleh orang tua dan pendidik bukan hanya tentang itu saja, sangat penting juga untuk menanamkan persoalan akhlak atau karakter. Apalagi melihat keadaaan dunia saat ini yang semakin berbeda. Pada zaman saat ini yang sering disebut zaman milenial ini marak sekali terjadi penyimpangan moral oleh anak bangsa. Karena banyak terjadinya penyimpangan moral tersebut perlu kiranya dunia pendidikan kita ini segera membenahi penanaman akhlak atau karakter kepada anak-anak bangsa ini agar generasi penerus tetap dapat menjaga budaya yang dimiliki bangsa ini. (Juwita, 2018; Prasetiya, Safitri, \& Yulianti, 2019)

Persoalan pendidikan yang terkait dengan moralitas senantiasa menjadi isue yang terus berkembang untuk mendapatkan penyelesaian khusunya imotralitas. (Bahar Agus Setiawan, Benny Prasetiya, 2019) Pelaksanaan pendidikan akhlak merupakan hal yang penting untuk diterapkan mengingat etika merupakan dasar manusia dalam mengatur hubungan dengan tuhannya maupun dengan sesama manusia (hablun minallah dan hablun min al-nas). (B. Prasetiya, 2018) Hal ini disebabkan karena dalam membangun sebuah peradaban manusia yang memiliki moralitas tinggi, Pendidikan akhlak memiliki peran yang sangat penting. Dengan adanya budaya dan peradaban yang baik akan membuat indahnya kehidupan bermasyarakat. sebab itulah pendidikan akhlak akan mampu membentuk kehidupan bermasyarakat yang penuh dengan kedamaian dan kerukunan. (B. Prasetiya, 2018)

Akhlak yg utama, kokoh, dan kuat, juga jiwa yang besar, obsesif dan ambisius, sangat dibutuhkan oleh manusia. Sebab dalam menghadapi berbagai tuntutan zaman yang baru tidak dapat dipenuhi kecuai dengan akhlak yang kuat dan tulus yang terpancar dari keyakinan yang mendalam, pengorbanan yang besar, ketegaran yang kokoh, dan mental yang tahan uji. Perubahan zaman akan selaras dengan perubahan akhlak dan keshalihan jiwanya. (Awaliyah \& Nurzaman, 2018)

Dalam pendidikan akhlak, Pendidikan Agama Islam (PAI) merupakan salah satu pilar yang terpenting. Pendidikan Akhlak akan mampu membangun dengan baik, jika dimulai dari menumbuhkan rasa keagamaan para murid. Karena itulah pelajaran PAI menjadi salah satu pelajaran yang sangat mendukung pendidikan Akhlak. (Rofi, Prasetiya, \& Setiawan, 2019; Kanji, 2021; Taufik, 2020)

Keluarga, sekolah dan masyarakat merupakan ruang utama pembentukan karakter dan akhlak anak dan remaja. (Juwita, 2018) Untuk mewujudkan pendidikan akhlak anak yang baik, haruslah dimulai dari keluarga terlebih dahulu. Dalam pelaksanaan pendidikan akhlak tersebut, keluarga hendaknya sangat memperhatikan kondisinya. Pada keluarga tradisional, kemungkinan satu-satunya bentuk kehidupan keluarga adalah ibu yang menjadi pengasuh anak dan pengurus rumah, sedangkan sang ayah aktif mencari nafkah dengan bekerja diluar rumah. Namun akan berbeda pendidikan akhlak pada keluarga dengan kedua orang tua yang bekerja dan anak diasuh oleh keluarga lainnya atau pengasuh bayi. (Ilyas, 2018 ; benny A. D. S. H. Prasetiya, 2019)

Dalam pendidikan akhlak, guru juga memiliki pengaruh yang sangat penting yakni tidak hanya menjadi pemberi materi pembelajaran, namun yang lebih penting lagi adalah sebagai contoh atau tauladan. Di beberapa media saat lalu, karakter guru telah tercoreng dengan adanya penyimpangan moral. Hal ini menjadi perhatian untuk mengembalikan karakter guru secara islami. Guru idealnya menjadi contoh pembentukan karakter bangsa dan agama. Dengan karakter itulah guru akan menjadi suri tauladan bagi muridnya dalam kehidupan sehari hari. (A. Setiawan, 2019; Khosiah, 2020) 
Dalam keluarga, keluarga, teman sekolah, dan masyarakat di sekitar anak-anak, pargaulan sangat memengaruhi pertumbuhan anak. pergaulan dalam lingkungan yang baik akan membuat anak memiliki kebiasaan perilaku yang baik. Lingkungan yang baik berasal dari interaksi langsung antara anak dan orang tua atau keluarga atau masyarakat, yang dapat dihasilkan dari interaksi tidak langsung antara anak dan kemajuan ilmu pengetahuan dan teknologi, seperti media sosial, youtube, TV, wifi, ponsel, playstation dan aplikasi lainnya. program. diharapkan anak-anak mampu mengakui kesalahan , mengendalikan diri mereka sendiri , memahami diri mereka sendiri , menerima orang lain, dan dapat bertindak sesuai dengan norma yang ada.(Herawati, 2020; Khosiah, 2019)

Lingkungan sosial saat ini mengkhawatirkan karena remaja telah melakukan banyak hal buruk. Lingkungan memberi kontribusi luar biasa bagi kehidupan, dan dapat membentuk kebiasaan bagi seseorang. Terutama pertumbuhan anak-anak yang masih bersekolah. Mereka akan kurang lebih mengikuti baik dan buruknya lingkungan. Meskipun semua orang menyaksikan perilaku orang-orang di sekitar mereka sangat memprihatinkan. Penurunan moral anak-anak saat ini dapat dilihat dari banyaknya remaja bahkan anak-anak yang memakai narkoba dan mabuk-mabukan, berkelahi, bolos, dan merayakan kelulusan mereka dengan cara yang tidak pantas. (Hidayati, 2019 Devy, Habibi Muhammad dan Agustiarini, 2020)

Al-Habib Abdullah Bin Alawi Al-Haddad adalah salah satu ulama yang telah mengkaji dan memberikan pendidikan akhlak secara mendalam. beliau adalah seorang 'Alim 'Allamah yang mengajarkan ummat di bidang pendidikan akhlak baik dari segi dzahir atau lahiriyahnya juga dari segi bathin atau hatinya. Sayyid Abdullah bin Alwy al-Haddad adalah salah satu dari beberapa tokoh sufi yang terkenal. Kitab maupun wirid yang ditulisnya dikenal luas di kalangan pesantren modern maupun pesantren salaf.(Sidiq, 2017)

Al-Habib Abdullah Al-Haddad adalah salah satu ulama yang patut dijadikan panutan baik dalam ucapan maupun amalannya yang mencerminkan tabiat dan akhlak mulia baginda Rasulullah SAW. Beliau bercita-cita tinggi dan mempunyai keinginan kuat dalam hal keagamaan. beliau juga selalu menangani masalah apa pun dengan adil dengan menghindari pujian maupun diutamakan oleh orang lain, Bahkan beliau selalu mempercepat tugasnya tanpa membuang waktu. Beliau dikenal dengan sifat mulia dan sifatnya yang pemurah, terlebih jika telah berada pada bulan ramadhan. Karakteristik inilah yang menyebabkan banyak orang-orang dari pelosok yang datang untuk berbuka puasa bersama beliau semata-mata untuk mencari barokah. (Al-Muhdhor, 2010)

Telah disebutkan bahwa di masa kecil beliau, al-Habib Abdullah mengerjakan shalat sunnah seratus rakaat setiap harinya setelah pulang dari rumah gurunya di waktu Dhuha.(Al-Muhdhor, 2010)

Disebutkan juga bahwa bahwa Habib Abdullah Haddad jarang tidur di malam hari kecuali sedikit saja karena ia menggunakan waktunya untuk beribadah. hal itu dikarenakan meneladani Baginda Rasulullah SAW. Telah disebutkan bahwasanya Al-Habib Abdullah Al-Haddad pernah berkata: "telah kami amalkan semua jejak nabi Muhammad SAW dan tidaklah kami meninggalkan sedikitpun daripadanya". ucapan Al-Habib Abdullah Al-Haddad tersebut dibenarkan dengan beliau memanjangkan rambut beliau hingga bahunya di akhir umur beliau, karena sebelumnya beliau berkata bahwa itulah sunnah yang belum beliau laksanakan. demikianlah rambut Rasulullah SAW yg diriwayatkan dalam suatu hadits. (Al-Muhdhor, 2010)

Selain dikenal sebagai seorang pendakwah dan guru besar dalam bidang pendidikan akhlak baik dzahir dan bathin, Al- Habib Abdullah Al-Haddad juga terkenal karena kitab-kitab yang beliau tulis. Banyak sekali kitab-kitab karangan beliau yang dikaji dan dibacakan di majelis maupun pondok-pondok pesantren di indonesia, salah satu dari kitab tersebut adalah Risalatul Mu'awanah. Istimewanya Kitab ini tergolong kitab yang kecil dan tipis karena sekedar risalah, namun di dalamnya telah banyak isi tentang ulasan dan uraian yang tentang nilai-nilai pendidikan akhlak yang telah disertai dengan dalil dan hujjah yang kuat, yang dapat dijadikan pedoman dalam mempengaruhi dan merumuskan nilai-nilai pendidikan akhlak didalam kehidupan atau aktivitas harian anak didik atau para murid.

Dari latar belakang yang tertulis diatas, penulis menjadi tertarik untuk mengkaji dan melakukan penelitian dengan judul "Nilai-Nilai Pendidikan Akhlak Dalam Kitab Risalatul Mu'awanah Dan Relevansinya" 
Penulis berkeinginan untuk mengetahui tentang nilai-nilai pendidikan akhlak dalam kitab Risalatul Mu'awanah dan bagaimanakah relevansinya dalam akhlak atau budi pekerti para anak didik, terutama dalam pendidikan di indonesia sekarang ini.

\section{METODE PENELITIAN}

Penelitian ini menggunakan model penelitian kepustakaan (library research). Dalam proses implementasi, peneliti mengumpulkan data model kualitatif, dan kemudian menggambarkan dan menganalisisnya dalam bentuk penelitian eksplorasi, yaitu, survei untuk tujuan memperoleh informasi, wawasan, pengetahuan, ide, ide, dan pemahaman, dalam upaya memberi rumusan dan definisi masalah dan membuat hipotesis.(Muhidin \& Syafri, 2016)

Penelitian kepustakaan (library research) mengacu pada penelitian yang dilakukan dengan mempelajari buku, manuskrip atau majalah dalam literatur yang terkait dengan masalah yang diambil sebagai penelitian. Semua informasi asalnya dari teks tertulis yang terkait dengan massalah dalam penelitian maupun dengan literature yang lainnya (Hadi, 2015)

Penelitian penulis dapat diklasifikasikan berdasarkan penelitian kepustakaan karena tidak perlu langsung memasuki lapangan melalui investigasi atau observasi untuk mendapatkan data yang diperlukan. Data yang diperoleh dan dikumpulkan dari penelitian perpustakaan adalah hasil dari membaca atau menarik kesimpulan dari berbagai buku, buku terjemahan dan karya ilmiah yang berkaitan dengan bahan penelitian dan topik.

Untuk memahami masalah yang sedang dibahas, penulis akan menggunakan metode deskriptif kualitatif, yang digunakan untuk mengungkap peristiwa atau fakta, situasi, fenomena, variabel dan situasi yang terjadi selama proses penelitian dengan menunjukkan apa yang sebenarnya terjadi..(Azwar, 2015)

Pendekatan filosofis juga penulis gunakan karena penelitian langsung mempelajari pemikiran atau gagasan Al-Habib Abdullah bin Alwi bin Muhammad Al-Haddad yang ada pada kitab Risalatul Mu'eawanah. Dengan cara ini, penulis dapat menunjukkan kekuatan dan kelemahan pemikirannya dibandingkan dengan karakter lain, dan mengusulkan sebuah solusi sendiri.(Bakker \& Zubair, 2020)

Dalam konteks seperti ini, penelitian tentang Nilai-Nilai Pendidikan Akhlak yang ada dalam kitab Risalatul Mu'awanah karangan Al-Habib Abdullah Al-Haddad akan sangat berarti.

Penelitian ini adalah penelitian kepustakaan (library research), dan semua pengumpulan data menggunakan penelitian kepustakaan, yaitu melalui metode membaca, mengkaji, dan meneliti dokumen-dokumen yang berkaitan dengan masalah yang akan dibahas. tekhnik yang dipakai dalam hal ini adalah tekhnik record, yakni mengumpulkan berbagai data dari berbagai macam dokumen yang ditemukan baik itu dari buku, thesis, artikel, jurnal dan lain sebagainya yang dibutuhkan dalam penelitian.(Moleong, 2018) Penelitian ini menggunakan metode rekord (dokumentasi) karena penelitian ini berjenis penelitian keputakaan (library research). Dimana data dicari dan ditemukan melalui metode membaca, mengkaji, mempelajari literatur yg terkait dengan pembahasan masalah, setelah memperoleh data maka data dikumpulkan, kemudian dianalisa dengan baik dan sesuai aturan yang telah ditetapkan.

Penelitian ini menggunakan metode analisis deskriptif analitik, yaitu dengan mengumpulkan dan menyusun data, kemudian menganalisis dan menginterpretasikan atau menjelaskan data, sehingga lebih tepat untuk menganalisis sesuai dengan isinya saja, hal ini disebut analisis konten atau content analysis.

Analisis konten / isi adalah teknik penelitian yang dapat digunakan untuk secara sistematis dan obyektif mengidentifikasi moralitas tertentu dari suatu pesan dari teks untuk menarik kesimpulan. 


\section{HASIL DAN PEMBAHASAN}

\section{Relevansi Nilai-nilai Pendidikan Akhlak Pada Kitab Risalatul Mu'awanah Dengan Pendidikan Akhlak Saat Ini \\ 1. Nilai Ilahiyah}

\section{a. Pendidikan untuk mencintai Allah SWT}

"Hendaknya Engkau Mencintai Allah swt, sehingga Allah swt lebih engkau cintai daripada yang lain-Nya, bahkan hingga tiada lagi yang engkau cintai kecuali DIA swt ".(Al-Haddad \& Al-Muhdlor, 2018)

Yang dimaksud cinta kepada Allah swt adalah memprioritaskan seluruh perintah Allah swt pada kehidupannya. Kecintaan kepada Allah SWT merupakan cinta tertinggi yang mengalahkan seluruh bentuk kecintaan kepada manusia, baik orang tua, istri, anak, harta benda, dan segalanya. Belum lagi menjadikan orang lain selain Allah posisi yang lebih tinggi di dalam cinta melebihi kepada Allah, meski hanya sama dan sederajat, hal ini merupakan sebuah kesalahan yang fatal.

Landasan cinta kepada Allah adalah mengenal terlebih dahulu, karena seseorang tidak dapat mencintai sesuatu tanpa mengetahui bentuk dan kepribadian orang yang ingin dicintai. Dapat dikatakan bahwa seorang hamba datang kepada Allah dalam situasi pemahaman yang benar, dan kemudian dia akan memiliki perasaan cinta, kerinduan dan cinta kepada Allah, karena cinta adalah hasil dari mengetahui, yaitu, mengenal Allah. Jadi, jika seseorang tidak mengenal mereka lebih dulu, mustahil untuk jatuh cinta.

Orang yang telah jatuh cinta pasti akan memberikan semuanya pada siapa yang dicintai, termasuk nyawa. Begitu pula halnya jatuh cinta kepada Allah, hal tersebut akan membuat seorang hamba berusaha memberikan dan melaksanakan seluruh apa yang diridhai Allah, seperti Nabi Ibrahim as yang cintanya pada Allah swt sangat dalam. Ia rela mengorbankan Nabi Ismail as pada Allah swt sebagai bentuk cintanya.

"Ketahuilah bahwa inti kecintaan adalah ma'rifah dan hasilnya adalah musyahadah dan paling rendah derajat cinta adalah rasa cinta kepada Allah swt itulah yang menguasainya hatimu dan yang membuktikannya adalah engkau tidak menuruti ajakan orang yang paling engkau cintai. Apabila ia mengajakmu untuk berbuat sesuatu yang mengundang murka Allah swt, seperti kemaksiatan atau meninggalkan sesuatu yang membuat-Nya murka seperti amal ibadah"

Ini sungguh sulit dilakukan, apalagi ketika orang diajak untuk tidak taat dan imannya tidak tergoyahkan, hal tersebut ,asih merupakan ekspresi cinta kepada Tuhan adalah yang paling rendah. Ketika telah kehilangan sifat buruk dari keberadaan manusia atau sifat insaniyah (seperti lupa dan berbuat salah), memberikan hidup kepada Allah SWT dan hanya mengingat Allah SWT, maka inilah cinta kepada Allah adalah yang tertinggi.

Cinta untuk Allah itu sangat perlu dan wajib hukummnya. Karena ini adalah salah satu wujud cinta yang tertinggi, dan kalaupun orang yang tinggal di dunia dengan dholim mengetahui nikmatnya mencintai Allah SWT, hal itu dapat membawa kehidupan seseorang tersebut ke alam tertinggi, sehingga mereka pasti tidak akan berbuat kedzaliman. Sebagaimana yang di firmankan dalam al-Qur'an surah Al- Baqarah ayat ke 165.

Berdasarkan dengan keyakinan, kesungguhan hati, dan pengakuan atas kekuasaan Allah SWT , Sang Maha Pencipta seluruh makhluk baik yang ada dibumi maupun langit, maka timbullah rasa cinta kepada Allah SWT, yang kemudian memunculkan cinta kepada Rasulnya yang diutus untuk seluruh ummat yakni Nabi Muhammad SAW. Hal ini telah tergambar dalam Al-Qur'an Surah Ali Imran ayat 31

Agar rasa cinta kepada Allah SWT dapat diwujudkan maka caranya disebutkan dalam ayat berikutnya, surat Ali Imran ayat 32 yakni dengan cara tha'at pada Allah dan Rasulnya.

Taatilah Allah dengan menjalankan isi Alquran dan taat kepada Nabi dengan mengacu pada hadits yang menjelaskan perintah dan larangannya. Ketaatan ini seragam. Jika Anda telah melakukan tindakan ketidaktaatan kepada Rasulullah SAW, maka ketaatan Anda kepada Allah SWT tidaklah sempurna, seperti yang ditegaskan dalam al-Qur'an surat An-Nisaa' ayat 80.

Telah Diriwayatkan tentang Sabda Nabi Muhammad SAW dalam shahih muslim yang memiliki mikna bahwasanya orang yang suka untuk bertemu Allah maka Allah swt pun suka untuk bertemu dengannya dan begitu juga sebaliknya. 
Hadits tersebut menjelaskan bahwa Allah SWT mencintai makhluknya yang mereka selalu siap bertemu dengan-NYA SWT dengan melakukan hal-hal yang baik dan meninggalkan apa yang dilarang Allah SWT sebelum maut datang..

Pendidikan cinta kasih kepada Allah SWT yang sangat relevan dengan kehidupan saat ini, dapat diterapkan pada kehidupan siswa saat ini dengan melakukan segala pekerjaan yang telah diwajibkan dan melakukan segala sesuatu yang menjauhkannya dari Allah SWT. dan Kembangkan dalam jiwa agar selalu bersyukur atas nikmat yang telah diperoleh.

Sejak remaja ia biasakan dengan membaca Alquran dan mempertimbangkan makna yang terkandung di dalamnya untuk menentukan perilaku mana dalam kehidupan sehari-hari yang diutamakan oleh Allah SWT. Setidaknya biasakan melakukan istiqomah antara shalat Maghrib dan Isya agar siswa dapat membaca Alquran kemudian melanjutkan belajar pelajaran umum yang dipelajari di sekolah.

Para pelajar perlu ditegaskan agar melakukan ibadah wajibnya terlebih dahulu, maka apabila yang wajib sudah dikerjakan, maka dianjurkan untuk menambahnya dengan ibadah yang sunnah dengan pelaksanaan yang istiqomah sebagai wujud cinta kepada Allah SWT.

Sebelum pelajaran pertama dimulai, hendaknya anak didik dihimbau untuk membaca Asmaul Husna dan dibiasakan hal tsb untuk membuka pintu ilmu dan agar dapat mengenal , merenungi dan memahami kebesaran Allah SWT.

\section{b. Pendidikan untuk ridha dengan segala ketentuan Allah SWT}

"Hendaknya engkau ridha terhadap semua ketentuan Allah swt yang ditetapkan kepadamu. Karena sesungguhnya ridha terhadap takdir termasuk hasil yang paling mulia dari cinta dan ma'rifat."(Al-Haddad \& Al-Muhdlor, 2018)

Rela atau ridha untuk menerima keputusan Allah adalah karena 'Percayalah pada diri sendiri, bahwasanya semua perbuatan Allah terjadi di sisi yang paling tepat, adil, terbaik dan sempurna. Umumnya manusia tidak bisa menerima ketentuan Allah SWT dalam hal bencana. Jika dihadapkan pada ketentuan Allah SWT berupa penyakit dan kesehatan maka manusia akan cenderung memilih sehat; ketika dihadapkan pada kesedihan atau kegembiraan maka manusia akan lebih cenderung untuk memilih pada kebahagiaan..

"jika seorang hamba ingin mengetahui keridhaan yang ia miliki,hendaknya ia mencarinya ketika turunnya musibah, ujian dan penyakit yang bertambah parah. Disitulah ia akan menemukan atau tidaknya. "(Al-Haddad \& Al-Muhdlor, 2018)

Dalam keadaan berduka cita karena menderita bencana, penyakit, dan kemiskinan, masyarakat diintruksikan untuk tidak mengeluh dan menyesali keadaan, karena itu merupakan wujud kesediaan untuk menaati Allah SWT. Bencana, penyakit, dan kemiskinan adalah bukti Ujian cinta hamba kepada Allah.

Allah SWT telah menjanjikan kemuliaan, keuntungan dan pahala yang besar pada orang yang ridha atau rela dengan semua ketentuan-NYA, sebagaimana yang difirmankanNYA dalam Al-qur'an surah Al-Mujadillah ayat ke 22dan surah Al-Baqarah ayat ke 8.

Sikap rela atau ridha dan menerima akan segala ketentuan Allah SWT ini haruslah ditanamkan kepada anak didik, hal ini bisa direlevansikan dengan selalu bersyukur atas nikmat yang telah diperoleh. seperti Apabila nilai ujian yang diperoleh belum dapat dikatakan bagus sedangkan dia sudah belajar dan berdoa kepada Allah, tetap harus dihimbau agar selalu bersyukur dan memberikan motivasi untuk Anak didik agar semangat belajar dan Doanya ditingkatkan.

Telah Diriwayatkan tentang sabda Nabi Muhammad SAW dalam shahih muslim yang memiliki makna bahwa Allah menetapkan RahmatNya lebih besar daripada murkaNya ketika DIA menciptakan makhluknya.

Allah telah menetapkan segalanya dalam hidup ini. Allah adalah Maha Mengetahui segala sesuatu yang telah terjadi dan yang belum terjadi. Oleh karena itu, manusia tidak perlu mengeluh tentang bencana yang mengganggunya, juga tidak harus terlalu bahagia disaat menerima berita gembira.

Untuk membentuk kepribadian Muslim yang sejati, sikap rela pada ketentuan Allah SWT perlu ditumbuhkan. Kata Muslim secara harfiah berarti "penyerahan" (aslama). Berarti kepribadian yang mestinya ada pada seorang muslim adalah sikap yang puas dengan segala ketentuan Allah. 
Namun sering kali pasrah atau berserah diri disalahartikan sebagai kemalasan atau tidak melakukan apa-apa. Ingat, setelah Nabi Muhammad s.a.w menginformasikan bahwa segala sesuatu ditentukan oleh Allah dalam menciptakan makhluk itu dalam hadits di atas, Nabi Muhammad s.a.w mengakhiri dengan menegur rahmat Allah SWT sebelum amarahnya. Karena itu, pasrah bukanlah malas. Berserah diri kepada Allah harus dibarengi dengan sikap serius mencari rahmat-NYA.

Pendidikan untuk rela dengan ketentuan Allah ini sangatlah relevan untuk diterapkan pada saat ini, seperti dengan cara membiasakan anak didik agar puas atau ridha dengan apa yang didapatkannya, menyedekahkan sebagian rezekinya untuk fakir miskin, dan juga memberi arahan secara aktif ketika terjadi suatu bencana atau musibah yang menimpa suatu kaum agar membantu mereka dan merenungi musibah tersebut, juga selalu memandang pada mereka yang berada dibawahnya dalam hal keduniaan, agar anak didik mempunyai sifat selalu rela dan bersyukur atas nikmat yang ada padanya.

\section{c. Pendidikan memperkuat keyakinan diri}

"Hendaknya engkau wahai saudara tercinta selalu menguatkan keyakinanmu dan memperbaikinya.(Al-Haddad \& Al-Muhdlor, 2018)

Keyakinan itu seperti kekuatan iman, dan keteguhan iman itu seperti gelombang besar. Tidak dapat diguncang oleh keraguan dan pikiran, bahkan tidak ada keraguan dan delusi. Jika tidak ada keraguan, telinga tidak akan mendengarkan, dan hati tidak akan berpaling padanya.

"diantara buah hasil keyakinan adalah, merasa tenang dan percaya pada janji serta jaminan Allah swt, beribadah kepadanya dengan penuh semangat, meninggalkan segala sesuatu yang membuatnya berpaling dari Allah swt, serta selalu kembali kepada Allah swt dalam setiap keadaan dan selalu berupaya sekuat tenaga untuk memperoleh keridhaan Allah swt.(Al-Haddad \& Al-Muhdlor, 2018)

Buah dari keyakinan tersebut antara lain perasaan tenang dan percaya pada janji dan jaminan Allah SWT, serta beribadah dengan penuh semangat. meninggalkan segala sesuatu yang menjauhkannya dari Allah SWT, dan selalu bertaubat kepada Allah SWT dalam keadaan apapun, dan selalu melakukan yang terbaik untuk ridha Allah SWT.

Hasil dari keyakinan tersebut yakni diberikan oleh Allah jalan kemudahan atas segala kesusahan yang menimpa dan diberikan nikmat rezeki oleh NYA. Sesuai dengan apa yang dijanjikan oleh Allah SWT dalam Al-Qur'an surah At-Thalaq ayat 2 - 3, dan juga surah AlAnkabut ayat ke 69.

Oleh karena itu, Keyakinan adalah inti dari keimanan dan fondasi utama dari semua posisi luhur. Moralitas terpuji dan bahkan perilaku saleh juga datang dari ranting dan buahnya. Kekuatan dan kelemahan, akhlak dan perilaku yang baik dan buruk bergantung pada keyakinan itu sendiri.

Keyakinan tidak lepas dari perbuatan yang benar atau amal shalih, dengan kata lain orang beriman adalah orang yang mewujudkan perbuatan benar atau amal shalih. Tidak hanya hatinya saja yang membenarkan dan lisannya, tetapi dia juga membuktikan imannya melalui perbuatannya yang baik. Sebagaimana yang disebtkan dalam Al-Qur'an surah Al'Ashr bahwa semuanya merugi kecuali yang beriman dan beramal shaleh juga saling menasihati pada kesabaran dan kebenaran.

Anak didik harus memiliki keyakinan yang kuat. Oleh karena itu, mereka akan selalu optimis dan rela melakukan sesuatu yang berguna bagi dirinya yang nantinya membuat mereka dapat hidup bahagia.

Untuk menanamkan keyakinan pada anak didik didik, disebutkan dalam kitab Risalatul Mu'awanah caranya yakni dengan memperhatikan seluruh makhluk Allah SWT bahwasanya dalam seluruh makhluk Allah terdapat tujuan dan maksud untuk apa Allah menciptakannya, contohnya seperti ; Allah SWT menciptakan kulit manusia yang gunanya untuk menutupi organ bagian dalam dari manusia tersebut. Dengan Memperhatikan dan merenungi seluruh makhluk Allah SWT dapat menumbuhkan keyakinan terhadap pencipta Makhluk tersebut.

Mencerminkan hal tsb dalam aktivitas anak didik sehari-harinya diberikan motivasi dan pemahaman bahwasanya masalah sebesar apapun pasti terdapat solusi dan pertolongan Allah didalamnya, sehingga anak didik memiliki keyakinan pada Allah SWT dan semangat dalam setiap masalahnya. 


\section{d. Pendidikan bersikap sabar}

"Hendaklah engkau bersabar. Karena sabar adalah pengendali segala urusan. Bagaimanapun juga engkau harus memilikinya selama engkau hidup di dunia ini. Karena ia termasuk budi pekerti dan hiasan yang baik”.(Al-Haddad \& Al-Muhdlor, 2018)

Merupakan kunci dari keimanan dan kebajikan, syarat terpentingnya adalah kesabaran, mulut dan lisan bisa dengan mudah terbuka untuk menyerukan tentang iman. Ribuan orang menyerukan iman, tetapi hanya puluhan orang yang mampu melanjutkan. Kebanyakan dari mereka jatuh di tengah jalan karena tidak tahan dengan rasa sakit karena kurangnya atau tiadanya kesabaran mereka.

Sabar adalah salah satu ciri utama orang yang memiliki ketakwaan. Beberapa ulama bahkan mengatakan bahwa kesabaran adalah setengah dari iman. Kesabaran terkait erat dengan iman: seperti kepala dan tubuh. Tanpa kesabaran, tidak ada keyakinan, karena tanpa kepala maka tidak ada tubuh yang bisa hidup.

Allah SWT menjadikan kesabaran sebagai senjata bagi mukmin untuk menghadapi segala persoalan dalam hidup. Orang yang sabar sama dengan orang yang murah hati yang tidak pernah miskin, pedang yang tidak pernah kehilangan ketajamannya. Inilah mengapa kesabaran dianggap dapat menyelesaikan berbagai masalah manusia dalam hidup.

Telah Diriwayatkan bahwasanya Rasulullah SAW bersabda sebagaimana yang terdapat dalam shahih muslim yang kira-kira maknanya adalah bahwasanya urusan seorang mu'min itu selalu baik, jika ia menerima nikmat maka dia bersyukur, dan jika mendapat musibah dia bersabar.

Sabar menghadapi segala ujian penyakit, kekurangan kebutuhan sehari-hari, bencana alam, dan peningkatan ketaatan kepada Allah SWT, dan bersyukur atas segala nikmat yang dimiliki merupakan sikap dari seorang mu'min..

Menurut Al-Ghozali, kesabaran itu adalah tak tergoyahkan, dan mengikuti pengaruh agama untuk menghadapi atau melawan pengaruh nafsu.(E. Setiawan, 2017)

Pembinaan kesabaran harus dimulai dari proses seseorang mencari ilmu, karena proses pendidikan merupakan awal dari pembinaan dan berlangsung lebih lama..

Pembiasaan sikap bersabar yang disebutkan didalam kitab Risalatul Mu'awanah relevan sekali dengan pendidikan Akhlak saat ini, tetap tenang saat menghadapi masalah, karena amarah tidak bisa menyelesaikan masalah, juga Berpikir jernih saat menyelesaikan masalah.

Menanggapi teman dengan kepribadian yang keras, bukan dengan tidak mau mengenal dan menjauh dari mereka, tetapi dengan saling menghormati pendapat dan menghindari argumen yang tidak menyenangkan.

\section{e. Pendidikan untuk memperbaiki niat}

"wahai saudaraku, sebaiknya engkau memperbaiki niat, memurnikannya, menimbulkannya, dan memikirkannya sebelum memulai melakukan amal perbuatan. Ketahuilah, bahwa niat adalah asas utama dalam sebuah perbuatan dan semua amal perbuatan akan mengikutinya, baik atau buruknya, dan benar atau tidaknya.(Al-Haddad \& Al-Muhdlor, 2018)

Niat adalah keinginan atau kemauan untuk bertindak. Niat adalah perkara hati. inilah yang pada dasarnya menentukan kualitas tindakan dan menjadikannya memiliki dimensi yang berbeda.

"sebagai syarat kesungguhan niat adalah tidak didustakan oleh amal perbuatannya. Contohnya, seseorang yang menuntut ilmu dan ia mengaku bahwa niatnya menuntut ilmu adalah untuk mengamalkan dan mengajarkannya, maka jika ia tidak melakukannya sedangkan ia mampu, berarti niatnya tidak benar. (Al-Haddad \& Al-Muhdlor, 2018)

Perbuatan dan niat memiliki hubungan yang terkait erat, dan perbuatan baik tanpa niat baik bisa menjadi sia-sia. Oleh karena itu niatkanlah seluruh perbuatan baik yang dilakukan untuk mencari ridha Allah SWT.

Kelalaian terhadap masalah niat ini dapat mengarah pada ibadah atau perbuatan yang baik tanpa mendapat pahala maupun ridha sang pencipta. Menunjukkan niat baik dalam setiap aktivitas akan membawa pahala yang besar. Ketika melakukan perbuatan baik dan ibadah, setiap tindakan dan ucapan akan memperhitungkan tujuan dan keyakinan batinnya juga.

Niat memiliki tempat dihati. Dan Allah SWT Maha Mengetahui segala sesuatu, tidak ada yang tersembunyi darinya, baik yang dzahir maupun yang batin atau didalam hati, baik yang dilangit 
maupun dibumi. Sebagaimana yang banyak diterangkan dalam Al-Qur'an seperti dalam surah AlAhzab ayat ke 54.

Niat merupakan aspek yang tidak terlihat dalam hati yang memiliki pengaruh besar terhadap apa yang didapatkan siswa dalam proses pembelajaran. Pendidik mempersiapkan dan menunjukkan niat peserta didik yang sesuai dengan tujuan utama peserta didik, yaitu menjadi individu yang secara aktif mendambakan kebaikan, kebenaran, dan ilmu. Tidak hanya mendengarkan, menerima dan mengingat, tapi juga mencerna.

telah diriwayatkan bahwasanya Nabi Muhammad SAW bersabda sebagaimana yang ada dalam shahih bukhari yang memiliki makna bahwasanya nafkah seseorang kepada keluarganya akan bernilai sedekah jika ia berniat mengharap pahala.

Niat adalah kondisi penerimaan tindakan. Niat adalah kemauan tertentu, meski tidak disertai dengan amal. Oleh karena itu, terkadang ini adalah ide yang bagus dan patut dipuji, dan terkadang itu adalah ide yang buruk yang harus dikutuk. Tergantung tujuannya, tapi juga driver dan pemicunya, tujuannya mencari ridha sesama manusia atau mencari ridha Allah SWT.

Dalam kitab risalatul mu'awanah, sikap selalu memperbaiki niat oleh anak didik ini sangatlah relevan dengan pendidikan saat ini, Dengan cara mendidik siswa dengan berdoa sebelum dan selama sekolah, memotivasi mereka agar mendapatkan motivasi, keinginan dan tujuan baik dari pekerjaannya sehingga mereka percaya bahwa mereka benar-benar akan berbuat baik.

\section{Nilai Insaniyah}

\section{a. Mengisi waktu dengan hal-hal yang bermanfaat}

"hendaknya engkau mengisi waktumu dengan berbagai aktifitas ibadah agar tidak berlalu sesaat pun baik malam atau siang hari melainkan selalu terisi dengan aktifitas ibadah. Sehingga nampaklah keberkahan waktu, diperoleh anfaat dalam umur ini dan akan selalu timbul semangat untuk beribadah kepada Allah swt. Selain itu luangkanlah waktu khusus untuk melakukan kebiasaan dan hobimu”.'(Al-Haddad \& Al-Muhdlor, 2018)

Waktu adalah salah satu berkah teragung dari Allah bagi umat manusia. Bagi manusia, sangatlah tepat untuk menggunakannya secara efektif dan efisien untuk memenuhi tugas sebagai makhluk ciptaan Tuhan di bumi. Setiap orang memiliki pemahaman dan konsep waktu yang berbeda. Beberapa orang merasa bahwa waktu mereka melimpah, tetapi beberapa orang merasa bahwa mereka sangat jelas memiliki waktu yang telah ditentukan sehingga dapat menggunakan waktu mereka dengan baik. Orang yang merasa punya banyak waktu, sering menyia-nyiakan waktu, dan sering menunda pekerjaan yang seharusnya diselesaikan.

Berbeda dengan mereka yang tahu dan bisa memanfaatkan waktu mereka sebaik-baiknya. Oleh karena itu, ia mengalokasikan waktu sesuai dengan prioritasnya, walaupun tidak ada keluaran dalam waktu yang singkat, ia tidak akan menyia-nyiakan waktu. Orang seperti ini juga akan melakukan pekerjaan penting dan mendesak (batas waktu) terlebih dahulu.

Kewajiban Islam dan adab-adabnya memiliki arti penting yaitu nilai waktu. Tugas ini memberi kesadaran dan peringatan pada manusia akan pentingnya waktu, peredaran planet, kemajuan matahari, bulan, dan pentingnya siang dan malam. Semua ini bisa memberikan pelajaran pada setiap muslim, agar senantiasa memahami siklus massa dan memantau pergerakan waktu yang diwariskan, agar tidak menunda jadwal sholat dan ibadah-ibadah lainnya dan agenda harian yang direncanakan.

"hendaknya engkau melazimkan untuk membaca buku-buku yang bermanfaat, yang tujuannya untuk menambah pengetahuanmu akan dzat Allah swt, ucapan-Nya, sifat-sifatNya, perbuatanNya dan kebesaranNya. Dengan membacanya, maka engkau akan mengetahui perintah-Nya kepadamu untuk engkau taati dan laranganNya untukmu agar engkau menjauhinya". (Al-Haddad \& Al-Muhdlor, 2018)

Tanggung jawab seseorang yang memiliki pengetahuan (ilmu) adalah mempraktikkannya. mempraktikkan ilmu atau mengamalkan ilmu tersebut harus berkelanjutan. Karena hanya dengan cara yang berkelanjutanlah, pengetahuan dapat menghasilkan buah. Pengetahuan yang tidak di amalkan atau dipraktikkan adalah seperti pedang yang dibawa para pelancong yang ketika mereka bertemu singa di tengah hutan, malah tidak digunakan.

Mengambil ilmu sebagai pekerjaan sehari-hari rutin (wirid) bisa membawa manfaat yang sangat besar. Manfaatnya sangat besar. Hal itu dapat membuat orang memahami, mengenal, dan 
berjalan ke arah kebenaran. Dan tidak mudah terpengaruh oleh riak laut yang mengganggu selama perjalanan.

Hidup adalah perjalanan panjang yang harus dilalui manusia. Untuk mencapai tujuan akhir dari perjalanan panjang ini, manusia membutuhkan segala macam persiapan dan berbagai alat untuk membantu mereka menghadapi kendala yang dihadapi dalam perjalanan. Perjalanan hidup tidak dapat diprediksi, penuh liku-liku, yang mungkin mengejutkan umat manusia. Pengetahuan yang berguna harus digunakan sebagai wirid, dalam arti, itu adalah dasar dari semua aktivitas kehidupan. Dengan menggunakan pengetahuan di semua aspek kehidupan, memungkinkan manusia mencapai tujuan akhir perjalanan dengan selamat

Ilmu yang menjadi wirid akan menyatu dengan manusia. Semua perilakunya tidak terlepas dari akhlak yang luhur. Semua tindakannya hanya untuk Allah. Kehidupan sehari-harinya adalah ketaatan padanya. Meninggalkannya adalah siksaan bagi hatinya.

Hatinya tidak mudah tergoyahkan oleh hal-hal duniawi. Karena hal-hal keduniawian hanya bersifat sementara dan pasti berakhir. Hal-hal duniawi tidak layak dikejar atau diperjuangkan. Namun, hal tersebut digunakan sebagai bekal dalam menempuh perjalanan panjang menuju akhirat.

Semua musuhnya, baik yang nyata maupun yang tersembunyi seperti nafsunya sendiri, bisa teratasi. Karena semua aibnya lah dia sadar bahwa dirinya tidak sempurna. Hal itulah ilmu yang dia miliki tidak menjadikan dirinya bangga dan sombong namun semakin rendah hati dan sadar akan dirinya. Orang yang waktunya dimanfaatkan untuk segala hal yang bermanfaat dan berfaedah merupakan ciri-ciri golongan mereka yang disebut sebagai Ulul Albab. Sebagaimana yang difirmankan Allah dalam Al-Qur'an surah Ali-Imran ayat ke 190.

Orang yang menyadari pentingnya pengaturan waktu pasti akan bertindak untuk dunia ini, seolah-olah dia akan hidup selamanya dan bertindak untuk dunia yang akan datang (akhirat), seolah-olah dia akan mati esok hari.Tentu saja ini akan menjadi slogan kehidupan.

Dalam menjalankan aktivitas sehari-hari perlu memanfaatkan waktu untuk mencari berkah dan sesuai cara yang baik seperti yang dicontohkan oleh nabi dan menyediakan waktu bagi Allah untuk ibadah dan menjaga keseimbangan antara dunia dan akhiratnya.

Bagi anak didik, banyak hal yang bisa dilakukan di waktu senggangnya. Waktu adalah hal yang sangat berharga, dan harus digunakan dengan bijak untuk menghasilkan sesuatu yang dapat Anda nikmati di masa depan. Terlalu banyak anak didik yang tidak memanfaatkan waktu luangnya secara maksimal, yang hanya akan membawa penyesalan di kemudian hari.

Anak didik lebih suka dengan aktivitas yang bersifat hedonis dan kurang bisa memakai waktunya untuk hal yang bermanfaat pada usia remaja atau masa-masa sekolah padahal usia tersebut merupakan masa-masa perkembangan dan masa untuk menemukan jati diri. Karena itulah, pendidikan untuk memanfaatkan waktu seperti yang terdapat di kitab "Risalatul Mu'awanah" sangatlah relevan dengan pendidikan yang ada saat ini, Membiasakan anak didik dengan pembuatan jadwal kegiatan sehari-hari, termasuk kegiatan belajar, jadwal kerja, dll, sehingga mereka terbiasa mengelola waktu lebih produktif sejak remaja tanpa harus meninggalkan belajar, kewajibannya untuk melaksanakan ibadah dan bermain dengan teman sebayanya.

Memanfaatkan waktu sepenuhnya berarti menjaga disiplin dalam mengatur waktu dan mengatur kegiatan yang perlu diutamakan. Tekankan bahwa siswa tidak boleh menunda pekerjaan sampai besok.

Waktu yang dihabiskan untuk suatu kegiatan bisa dimanfaatkan dengan baik sambil melakukan kegiatan anak didik yang lain. Misalnya, waktu yang dihabiskan saat memakai transportasi umum ke sekolah dapat digunakan untuk membaca buku atau meningkatkan daya ingat dengan menghafal dll..

Dimungkinkan juga untuk dalam pendidikan mengatur waktu untuk menyalurkan hobinya seperti bermain alat musik, menggambar, dan otomotif, komputer dll sebagai sarana yang tujuannya agar kegiatan hedonik menjadi wadah untuk belajar dan mengasah ketrampilan yang terdapat pada diri anak tersebut. Dan sudah tentu memanfaatkan waktu untuk hobi memiliki keterbatasannya agar tidak lupa untuk beribadah kepada Allah SWT. 
Berkumpul bersama anggota keluarga dan membantu orang tua pada kegiatan sehari-harinya dalam pemanfaatan waktu luang juga sangat penting. Jika orang tua dalam kesulitan, maka anak harus berusaha semaksimal mungkin untuk mengurangi beban orang tua. Jika keadaan keuangan orang tua lemah, anak harus berusaha mencari penghasilan lain di luar jam sekolah dengan cara yang baik dan terpelajar. Jika orang tua membutuhkan kekuatan anak-anak mereka untuk mencari nafkah, maka tolong dan bantu mereka semaksimal mungkin.

Untuk pemanfaatan waktu yang tujuannya beribadah kepada Allah SWT, anak didik diajarkan agar dalam kegiatan sehari-harinya memiliki rutinitas selain mencari ilmu, seperti mengerjakan sholat sunnah yang dikerjakan dengan istiqomah. Karena itulah anak didik perlu dibiasakan dengan membuat jandwal-jadwal ibadah disekolah seperti pelaksanaan sholat sunnah dhuha setiap pagi dan pembacaan istighotsah pada jum'at pagi dll.

\section{b. Adab dalam melaksanakan kegiatan sehari-hari}

"hendaknya engkau selalu menjaga adab-adab sunnah secara dzahir dan batin. Begitu juga dalam ibadah dan kebiasaan, sehingga engkau mengikuti jejak Rasulullah saw, rasul rahmat dan nabi pembawa petunjuk ini dengan benar-benar sempurna."(Al-Haddad \& Al-Muhdlor, 2018)

Adab adalah inti ajaran Islam dan tujuan Rasulullah SAW diutus. Seperti yang kita ketahui bersama, Rasulullah saw diutus ke muka bumi ini untuk mendidik manusia agar menjadi manusia yang mulia. Oleh karena itu, manusia harus selalu mencontoh beliau SAW dalam kehidupan sehari-hari.

Islam adalah agama yang sempurna, yang mengatur segala perbuatan manusia dari bangun hingga tertidur kembali, dan menjadi pedoman bagi aktivitas manusia.

Membicarakan tentang adab sejalan dengan ajaran Islam itu sendiri. Hal ini dikarenakan terdapat beberapa unsur penting dalam adab yaitu aqidah, ibadah, adab dan muamalah, unsurunsur tersebut tidak dapat dipisahkan. Ketika salah satu dari hal ini dilupakan, dunia dan akhirat akan menjadi tidak seimbang. Al-Qur'an surah. Al- Furqon ayat ke 63 dan surah An-Nahl ayat ke 90 telah menjelaskan hal yang demikian tersebut.

Adab sangatlah penting bagi manusia, karena adab menginstruksikan manusia untuk berperilaku baik dan menjauhi perilaku buruk. Selain bisa menyesuaikan dan menuntun manusia pada fitrahnya yaitu beribadah dan menaati cahaya petunjuk dari Allah SWT melalui ibadah yang benar, niscaya manusia dapat melindungi diri dari pikiran dan perbuatan yang menyesatkan. Oleh karena itu, pemahaman yang benar tentang pendekatan ini juga dapat memurnikan kepribadian. Oleh karena itu, dapat dikatakan bahwa semakin tinggi pengetahuan seseorang maka semakin tinggi pula kepribadian orang tersebut.

Pendidikan Akhlaq merupakan salah satu prosedur pembelajaran, dan membangun relasi antar sesama harus dilandasi dengan kualitas akhlak yang baik. Dalam pemahaman filosofi Islam, akhlak merupakan salah satu hasil keimanan dan ibadah, tidaklah dikatakan menjadi sempurna keimanan dan ibadah kecuali jika konsep akhlak mulia dan akhlak muncul pada hubungannya dengan Allah dan makhluknya, jika tidak, maka keyakinan dan ibadah manusia tidak akan sempurna. jika Sejak awal masa remaja atau dalam proses mencari ilmu telah menyesuaikan diri dengan kesopanan dan telah menjadi kebiasaan, maka anak didik akan terbiasa dengan kesopanan hingga dewasa.

Adab saat melaksanakan kegiatan-kegiatan harian yang ada pada kitab "Risalatul Muawwanah" seperti saat memakai pakaian disunnahkan agar pakaiannya menutup aurot, mulai memakai pakaian dengan doa dan dari bagian yang kanan, saat berbicara, anak didik dibiasakan berbicara dengan suara yang pelan dan berbicara dengan tertib dan tidak berbicara yang ngawur, bila ada kawan atau seseorang yang menceritakan sesuatu dan hal tersebut kurang benar, maka koreksi dengan baik dan nada yang halus, dalam hal berbicara hendaknya menjauhi perkataan yang kasar, kotor, ghibah, namimah serta bercanda yang berlebihan. Apabila lawan bicaranya adalah orang yang lebih tua, maka menggunakan kalimat yang sopan dan halus sebagai bentuk mengagungkannya dan hal ini semua sangat relevan untuk pendidikan saat ini.

Pada saat berjalan maka adabnya adalah seperti saat keluar wc atau rumah maka didahulukan kaki kiri, membiasakan berjalan dengan tidak terburu-buru ataupun dengan lamban yakni dengan kecepatan yang sedang. Tidak memakai satu sandal saja baik itu jika sandalnya rusak ataupun hal lain meski jaraknya dekat. Dibiasakan agar tidak tolah-toleh saat berjalan seperti untuk melihat 
kaca jendela, gambar dll apalagi untuk melihat mereka yang bukan mahramnya. dan memulai menyapa dengan salam jika bertemu orang lain.

Adab ketika duduk yakni membiasakan agar duduknya tenang dan tegak tidak membiasakan hal buruk seperti memasukkan jari ke mulut, telinga maupun mengorek hidung. Serta jangan memindah orang lain dengan menyuruhnya berdiri dari tempat duduknya.

Pada saat akan tidur agar membaca doa dan memohon perlindungan Allah pada saat tidurnya dijadikan kebiasaan dan meniatkan tidurnya tersebut untuk beristirahat agar memiliki kekuatan untuk beraktivitas atau ibadah besok, menghindari tidur yang terlalu lama dan larut malam, cukupkan 8 jam untuk waktu tidur. Dan posisi tidurnya menghadap kiblat dan menghadap kiblat dan berbaring pada sisi yang kanan .

Pada saat makan dan minum adabnya adalah berdoa pada saat memulai dan bersyukur setelah selesai makan dan minum,. Jangan tergesa-gesa dan hindarilah bersendawa, biasakanlah agar mencuci tangan sebelum makan dan sesudahnya, jika ingin meludah atau membuang ingus maka adabnya yakni menyingkir atau menjauh terlebih dahulu dari majelis, minum saat keadaan duduk dan menghindari minum di gelas yang retak dan minum langsung dari mulut kendi, semua ini sangat relevan diterapkan dalam pendidikan saat ini dan jadikanlah hal ini kebiasaan pada anak didik.

\section{c. Menjaga kebersihan diri}

"hendaknya engkau selalu tampil bersih, rapi secara dzahir dan bathin. Sesungguhnya orang yang telah sempurna kebersihannya, maka dengan hati dan jiwanya ia bagaikan malaikat rohani, meskipun dengan tubuhnya dan tampangnya ia manusia jasmani..(Al-Haddad \& Al-Muhdlor, 2018)

Salah satu kebutuhan dasar peserta didik adalah terpenuhinya kesehatan batin dan badan. Kesehatan adalah wujud anugrah Allah SWT yang harus dijaga dan dimaknai bersama.Ini merupakan kewajiban agar berjuang untuk hidup sehat dalam kehidupan sehari-hari, Baik itu kesehatan badan maupun batin, dengan mewujudkan perilakunya dengan akhlak yang baik. Orang yang memiliki Akhlak seperti ini disamakan seperti malaikat meski dia seorang manusia.

"kebersihan batin bisa diperoleh melalui pembersihan diri dari akhlak yang bruk, seperti sombong, riya', dengki, cinta dunia, dan lain sebagainya. Juga bisa diperoleh dengan menghiasi diri dengan akhlak yang mulia,seperti rendah hati, rasa malu, ikhlas, murah hati dan lain sebagainya. Adapun Kebersihan dzahir dapat diperoleh dengan meninggalkan kemaksiatan dan menjalankan ketaatan. Barangsiapa yang menghiasi dzahirnya dengan melazimi amal-amal shaleh, memakmurkan hatinya dengan budi pekerti yang baik, berarti telah sempurna kebersihannya." (Al-Haddad \& Al-Muhdlor, 2018)

Sisi Manusia terdiri dari batin (jiwa) dan dzahirnya (fisik). Kebersihan adalah yang layak didapatkan umat manusia. Karena kebalikan dari kata "bersih" adalah kotor, yang selalu membuat orang merasa tidak nyaman. Tidak ada yang menganggap kotoran adalah hal yang baik dan pantas untuk dicari.

dikarenakan kebersihan adalah hal yang harus dimiliki manusia supaya bisa merasakan kenyamanan hidup, maka pembersihan diri harus selalu dilakukan oleh manusia. Sebagaimana dikatakan habib Abdullah bin Allawi Haddad di atas, pembersihan diri dari sudut pandang batinnya dilakukan dengan membersihkan diri dari konsep moral yang keji. Membersihkan diri dari akhlak yang hina ini dalam terminologi tashawwuf hal ini disebut takhalli, setelah akhlak yang keji di dalam jiwa dikosongkan, ia dihias dengan akhlak yang terpuji. Yang Dalam terminologi tashawwuf hal ini disebut tahalli.

kemudian dari segi dzahirnya, pembersihan diri dilakukan dengan cara memperbanyak perbuatan-perbuatan baik. Perbuatan baik merupakan kegiatan badan yang tidak melanggar larangan Allah dan bertujuan untuk mencari Ridhanya. Perbuatan baik ini bisa dilihat dari segi lahiriahnya namun kebaikannya tidak bisa dilihat dari sisi batinnya. Pembersihan diri dari sisi dzahir dan bathin inilah yang bisa menunjukkan kebersihan secara sempurna pada manusia.

Al-Qur'an telah menerangkan perihal menjaga kebersihan ini seperti dalam ayat ke 222 dalam surah al-Baqarah yang membahas perihal haidh.

Ayat tersebut menjelaskan bahwa Allah memerintahkan umatnya untuk tetap bersih karena Allah menyukai ummatnya yang bersih atau mensucikan diri. Mesucikan diri dengan menjaga 
kebersihan akan menciptakan lingkungan yang sehat dan hidup bersih. Oleh karena itu, hal tersebut juga akan mempengaruhi kehidupan manusia yaitu menciptakan lingkungan yang bersih dan sehat.

Pendidikan agar menjaga kebersihan diri untuk anak didik yang telah termuat di kitab "Risalatul Mu'awanah" sangatlah relevan dengan Pendidikan saat ini seperti pendidikan Akhlak tentang menanamkan sikap selalu membuang sampah yang ada dijalan maupun yang terdapat dalam fikiran yang bisa mengganggu jalan umum maupun mengganggu ibadah kepada Allah. Menjaga kebersihan fisik seperti mandi dan selalu berwudhu sebelum berangkat mencari ilmu, berpakaian rapi dan bagus dan menjaga pakaian dari najis agar bisa selalu digunakan untuk ibadah maupun mencari ilmu.

Biasakan mengubah sikap anak didik agar jangan membuang sampah sembarangan. Jika anak didik membawa sampah dan tempat sampah tidak ditemukan, maka harap menyiapkan kantong plastik dan kumpulkan di sakunya. Jika sudah ditemukan maka buanglah pada tempatnya.

Sedangkan dalam Menjaga kebersihan diri dari kotoran yang bathin di relevansikan dengan mengabdikan diri kepada Allah dan mengikuti Rasulullah SAW, selalu membaca sholawat kepada baginda nabi untuk menjaga kebersihan bathin yang bisa berkhasiat untuk menjernihkan hati maupun dengan berdzikir kepada Allah SWT. Dan selalu menjaga niat agar ikhlas dalam melakukan perbuatan-perbuatan tersebut agar dapat terasa dampaknya dalam menjernihkan hati.

d. Berbakti kepada orang tua

"hendaknya engkau berbakti kepada kedua orang tua, karena hal ini termasuk kewajiban yang paling utama. Janganlah engkau mendurhakai mereka, karena hal itu termasuk dosa yang terbesa" (Al-Haddad \& Al-Muhdlor, 2018)

Termasuk kebaikan yang diberikan oleh anak kepada orang tua mereka adalah berbakti kepadanya. Hal ini sudah meliputi kebaikan baik dari segi dzahir maupun bathin. Dan hal ini merupakan kebaikan yang memang sudah menjadi hal yang lumrah bagi kemanusiaan meski mereka tidak memiliki keimanan pada Allah maupun hari akhir.

Berbakti tersebut bisa dengan hal harta, tenaga, kedudukannya dan lain sebagainya termasuk juga saat berbicara dengan baik pada mereka, sebagaimana yang telah diperintahkan oleh Allah swt dalam Al-Qur'an surah Al-Israa' ayat ke 23.

dalam hal perbuatan hendaklah seorang anak selalu mendoakan kedua orang tuanya dan selalu mentaati setiap perintah mereka dan bersikap sopan dan baik pada mereka sebagaimana yang disebut pada ayat berikutnya yakni surah Al-Israa' ayat ke 24 .

Gunakan kerendahan hati, rasa hormat dan sopan santun untuk berbicara dengan baik kepada orang tua, dan selalu doakan mereka sebagai anak yang dibesarkan oleh orang tuanya. Jangan sampai melukai hati mereka karena mengucapkan sepatah kata yang menyinggung.

Diriwayatkan tentang sabda Rasulullah saw dalam shahih muslim yang memiliki makna bahwa sholat tepat waktu dan berbakti pada orang tua adalah perbuatan-perbuatan yang paling utama. Maka lihatlah petapa penting dan agungnya berbakti kepada orang tua sampai disejajarkan dengan sholat tepat waktu.

Disebutkan juga dalam shahih muslim bahkan rasulullah menyebut celaka sampai tiga kali bagi seseorang yang orang tuanya hidup sampai masa renta namun dirinya tidak masuk surga karena tidak merawat mereka, karena sudah sepantasnya kita merawat mereka disaat mereka telah tua renta sebagaimana mereka merawat kita saat kita masih kecil.

Pendidikan perihal berbakti kepada orang tua yang termuat dalam Risalatul Mu'awanah ini sangatlah relevan dengan pendidikan akhlak saat ini. Perilaku anak didik yang berjuang untuk mendapatkan ridha orang tua adalah mematuhi perintah mereka dengan cinta dan hormat. Selalu tersenyum di hadapan mereka dan berjabat tangan atau memberi salam atau pamit kepada mereka setiap keluar rumah. Instruksikan juga anak didik untuk mencari pertimbangan dan persetujuan atau restu mereka ketika hendak mengerjakan sesuatu..

Selalu berhati-hati terhadap sikap dan kata-kata yang mungkin bisa saja menyakiti mereka, yakni haruslah berbicara kepada mereka berdua dengan kata-kata yang lembut. Ini harus dibedakan dengan berbicara dengan kedua orang tua dan berbicara dengan teman atau orang lain. Jangan tunjukkan ekspresi tidak menyenangkan saat orang tua memberikan saran atau perintah 
untuk melakukan sesuatu. Saat mereka memberikan nasehat, jangan menatapnya dengan tajam, dan jangan meninggikan suara dihadapan mereka melebihi suara mereka.

Doakan selalu umur panjang, dan dimudahkannya rezeki mereka, telah maklum hadits yang menerangkan bahwa ridha allah ada dalam ridha orang tua, begitu juga kemarahannya. Jika orang tua sudah wafat mendahului maka cara untuk berbakti kepada mereka adalah dengan mendoakan mereka agar diampuni dosa dan kesalahan mereka, menyambung tali silaturahmi dengan sahabat dan kerabat dari orang tua dan juga bersedekah atas nama mereka.

\section{e. Amar ma'ruf (memerintahkan kebaikan) nahi mungkar (melarang kemungkaran)}

"hendaknya engkau menyeru pada kebaikan dan mencegah terhadap kemungkaran. Karena hal ini adalah sendi-sendi dalam agama.". (Al-Haddad \& Al-Muhdlor, 2018)

Memerintahkan kebaikan (amar Ma'ruf) dan melarang kemungkaran (nahi munkar) adalah tiang-tiang penting dalam agama.berpedoman dengan agama untuk memerintahkan kepada yang baik yang sesuai dengan syariat dan melarang kemungkaran yang dilarang atau merupakan hal yang buruk menurut syariat agama. Amar ma'ruf dan nahi munkar ini bisa dilaksanakan dengan sempurna karena rasulullah telah diutus untuk menyempurnakan akhlak manusia.

Sebagai ummat nabi Muhammad SAW, Telah disempurnakannya agama ini, di ridhai oleh NYA sebagai agama satu-satunya untuk seluruh manusia.sebagaimana yang difirmankan Allah SWT dalam al-Qur'an surah al-Maidah ayat ke 3.

Pendidikan agar mengerjakan amal ma'ruf nahi munkar yang termuat di kitab "Risalatul Mu'awanah" sangatlah relevan pada lingkungan sekolah anak didik yakni Jika seorang temannya melakukan kesalahan atau tindakan yang dilarang oleh agama atau melanggar peraturan sekolah, maka sudah seharusnya dia mengeluarkan peringatan dengan cara yang lembut dan penuh kasih melalui tindakan yang reprehensif. Instruksikan anak didik untuk memiliki karakter yang baik. Jadikan itu panutan bagi rekan-rekannya. Jangan diam saat temannya melakukan kesalahan atau kedzaliman seperti bullying dll.

Juga mengedepankan nilai tasammuh atau toleransi sehingga tetap menyuruh kebaikan dengan cara yang baik dan melarang kejahatan dengan cara yang baik juga hingga pelaku kemaksiatan menjadi tersentuh yang menjadikan dia meninggalkan kemaksiatan dan takut melakukannya kembali.

\section{f. Meghindari banyak bercanda}

"hindarilah ghibah, mengadu domba dan banyak bercanda. Hindarilah segala ucapan yang buruk, tahanlah dirimu dari ucapan tercela sebagaimana engkau tidak mau mendengar ucapan yang buruk pula. Pikirkan ucapanmu sebelum engkau bertutur kata. Jikalau memang itu baik, maka ucapkanlah, namun jikalau tidak, maka diamlah". (Al-Haddad \& Al-Muhdlor, 2018)

Ada rasa humor dalam bercanda, karena lelucon biasanya menghasilkan tawa. Bercanda adalah cara yang esensial dan unik untuk menarik simpati dari banyak orang.

Pendidikan agar menghindari lelucon yg berlebihan tentu sangatlah relevan dengan pendidikan moral saat ini. Kembangkan sikap untuk menghindari lelucon yang akan melecehkan orang lain untuk membuat teman lain bahagia. Gunakan kata-kata yang tepat untuk bercanda dan bercanda sewajarnya saja.

Bicaralah dengan lembut dan tersenyumlah dengan teman-teman. Siswa disarankan untuk tidak meninggikan suara atau berbicara buruk kepada teman sebayanya. Saat pelajaran berlangsung, jangan bercanda dengan teman lain, dan dengarkan pelajaran dengan tenang tanpa mengganggu teman yang sedang memahami topic pembelajaran.

Saat bercanda, jangan membuat teman lain tertawa dengan menyembunyikan alat-alat seperti pensil dari teman yang lain, agar tidak mengganggu teman tersebut. Saat istirahat, lebih baiknya bermain bersama di halaman atau diluar kelas daripada tetap berada didalam kelas. Hindari lelucon yang bisa saja merusak persahabatan.

Di satu sisi, bercanda bisa menimbulkan keakraban antar teman, namun di sisi lain bisa menimbulkan perselisihan. Karena itu, yang terbaik adalah tidak bercanda. Karena manusia adalah makhluk yang tidak pernah lepas dari yang namanya lupa dan kesalahan, mereka bisa melampaui batas selama mereka merasa bahagia. Oleh karena itu, sering kali dibuat berlebihan dalam lelucon. Lelucon yang melebihi batas ini bahkan bisa menyakiti perasaan teman. 
Selain itu, bercanda bisa menurunkan harga diri manusia. Mungkin suatu saat seseorang ingin berbicara dengan serius, tetapi karena sikapnya yang sering bercanda, percakapannya tidak ditanggapi dengan serius.

\section{g. Memuliakan Guru}

"Hendaknya engkau menghormati umat islam terutama orang-orang yang memiliki keutamaan seperti kalangan ulama, orang-orang shaleh, orang-orang mulia dan orang-orang yang telah lanjut usia dalam islam”. (Al-Haddad \& Al-Muhdlor, 2018)

Pendidikan tentang Memuliakan guru yang termuat didalam kitab "Risalatul Mu'awanah" sangat erat kaitannya dengan pendidikan akhlak saat ini,cara menanamkannya adalah dengan duduk santun di depan guru dan berbicara dengan tata krama yang santun untuk menanamkan rasa hormat kepada guru sebagaimana rasa hormat kepada orang tua. Saat mendapat nasehat, anak didik diajarkan agar tidak memotong percakapan dan menunjukkan wajah yang tidak menyenangkan.

Dengarkan baik-baik pelajaran yang diberikan.Jika metode yang diberikan oleh guru tidak membantu untuk faham, anak didik diajarkan harus mengajukan pertanyaan dengan tenang. Dengan mengangkat tangan terlebih dahulu agar guru mengizinkan mengajukan pertanyaan. Bersemangatlah saat kelas dimulai. Dan biasakan anak didik terbiasa dengan sopan santun untuk izin sampai mendapatkan izin saat ingin meninggalkan kelas.

Tanamkan sikap tawadhu' dan tinggalkan sifat sombong dalam mencari ilmu. Tanamkan juga sikap rendah hati ini kepada orang yang lebih tua lebih-lebih kepada orang tua sendiri hingga terwujud dalam kepribadian sehari-harinya dengan kesopanan dan keluhuran budi.

Jangan melupakan rasa terima kasih kepada guru atas kesungguhannya dalam mendidik anak didiknya dan mengasah potensinya. Jangan lupakan kebaikan yang diberikan guru. Jangan menampakkan aib guru dan memulai mengucap salam saat bertemu baik itu di jalan maupun disekolah.

\section{h. Tolong Menolong}

"hendaknya engkau menghibur hati orang-orang yang susah, berlemah lembut terhadap orang-orang yang lemah dan miskin, membantu orang-orang yang tidak punya, memberi kemudahan bagi orang-orang yang kesulitan, memberi pinjaman bagi orang yang meminjamnya". (Al-Haddad \& Al-Muhdlor, 2018)

Manusia adalah makhluk yang memiliki banyak kekurangan. Karena manusia memiliki berbagai kekurangan, maka manusia memiliki sifat dasar saling membutuhkan pertolongan dari yang lain. Dengan menyadari keterbatasan ini dan mensyukuri atas kelebihan yang telah diberikan-NYA, seseorang sudah seharusnya membantu siapapun yang membutuhkan. Itu bahkan tidak terbatas pada manusia saja. Tidak peduli penduduk bumi manapun yang membutuhkan bantuan, mereka harus dibantu. Karena setiap orang saling membutuhkan pertolongan. maka, setiap orang harus saling melengkapi untuk mencapai keseimbangan dalam hidup.

Diriwayatkan sebuah hadits tentang Sabda Rasulullah saw yang menyuruh umatnya untuk membagi sebagian daging kurban mereka untuk membantu kondisi sosial. Hal ini memberikan pelajaran bagi siapa saja untuk membaca kondisi sosial. Ketika masyarakat sekitar membutuhkan bantuan, maka sikap membantu mereka mengurangi masalah adalah hal yang perlu dilakukan. Dengan membantu tetangga atau orang yang bermasalah maka akan terjalin suasana cinta dan harmonis antara tetangga dan masyarakat..

Sikap saling membantu erat kaitannya dengan pendidikan moral saat ini, ketika tetangga melakukan kegiatan pengabdian masyarakat atau kegiatan sosial hendaknya mereka mengembangkan sikap yang positif dan saling bekerjasama. Berpartisipasi dalam membantu tetangga atau komunitas yang sedang menghadapi bencana.

\section{i. Bersikap Ramah}

"hendaknya engkau tersenyum di wajah orang-orang yang beriman, berwajah cerah, menampakkan kegembiraan, bertutur kata yang baik dan bersikap rendah hati terhadap mereka".(Al-Haddad \& Al-Muhdlor, 2018)

Agar bisa mendapati tempat yang aman, sejahtera, damai dan tentram, anak didik perlu diajarkan agar berinteraksi dengan baik dengan lingkungan dan tetap akrab dengan tetangganya, seperti menjalin persahabatan yang baik. Rukunlah dengan teman-teman tetangga, yaitu 
bermainlah dengan sopan. Jika sedang ingin meminjam sesuatu, maka haruslah meminta ijinnya dulu. Jangan bermain-main dengan mengotori halaman atau dindingnya.

Diriwayatkan bahwasanya Rasulullah SAW memerintahkan untuk memuliakan tetangga lebih-lebih yang terdekat dalam sebuah hadits yang diriwayatkan imam bukhari.

Diperintahkan oleh Rasulullah SAW untuk menghormati tetangga, saling menghormati dan membantu satu sama lain jika terjadi bencana.

Menjaga hubungan bertetangga agar tidak bertengkar dan sesumbar tentang pakaian atau apapun yang termuat didalam Risalatul Muawwanah ini erat kaitannya dengan pendidikan akhlak saat ini. penanamanya dengan cara mengunjungi dan mendoakan tetangga yang sakit, dan jangan membuat suara bising yang menimbulkan gangguan. Serta sering menyapa saat bertemu di jalan.

\section{j. Bersimpati}

"hendaknya engkau menampakkan kegembiraan dan keceriaan pada setiap kegembiraan yanng dialami oleh umat islam seperti turunnya hujan, turunnya harga dan kemenangan mereka atas orang-orang yang dzalim dan orang-orang kafir". (Al-Haddad \& Al-Muhdlor, 2018)

Sikap bersimpati kepada orang lebih-lebih pada tetangga didalam bermasyarakat bisa direlevansikan oleh anak didik dengan cara menampakkan sikap simpati dan menunjukkannya saat terdapat tetangga yang mengalami musibah. Sikap bersimpati ini bisa ditunjukkan dengan tidak berbahagia saat ada yang mengalami musibah baik dengan tertawa dihadapannya atau memakai pakaian bagus yang mewah maupun bercanda dihadapannya dengan orang yang lain.

Bersimpati dengan sesama Muslim atau manusia terkadang sulit. Seperti Saat turun hujan, banyak orang yang melupakan bersyukur dengan berbagai alasan. Bahkan lupa bahwa beberapa saudaranya yang muslim atau manusia lain masih banyak yang butuh hujan. Banyak orang membicarakan tetangganya ketika tetangga tersebut mampu untuk membangun rumah, bukannya turut senang. Ketika harga sayuran naik, banyak yang merasa resah, padahal petani-petani membutuhkan kenaikan harga tersebut.

Diriwayatkan sabda Rasulullah saw tentang pentingnya sikap simpati ini bahkan sampaisampai beliau saw tidak menganggap mereka yang tidak prihatin terhadap urusan umat islam sebagai golongan umat islam yang sebenarnya.

Simpati atau Welas asih adalah menghargai kenikmatan yang diterima orang lain atau perhatian terhadap bencana yang diderita orang lain. Sikap ini dibutuhkan untuk membangun hubungan sosial yang baik. Sikap ini diperlukan untuk memperkecil jarak antara yang terpinggirkan dan yang berlebihan.

Sayangnya, rasa simpati atau welas asih ini tidak tertanam dalam di hati kebanyakan orang. Apalagi di era sekarang ini, kebanyakan orang lebih mementingkan kepentingan atau kepentingan kelompoknya sendiri, daripada bersimpati dengan mereka yang terpinggirkan dan membutuhkan bantuan.

Maka karena hal tersebutlah, Al-Habib Abdullah al-Haddad memberikan nasihat kepada siapapun agar menampakkan atau memiliki rasa simpati kepada sesame manusia. Hal ini sangat terkait dengan pendidikan akhlak sekarang. Ekspresikanlah hal ini dengan semacam kebahagiaan dan kegembiraan. maka Dengan kasih sayang seperti ini, saudara dan saudari akan merasa dihargai dan diperhatikan. Dengan simpati tersebut, tampaklah bahwa persahabatan sesama muslim dan sesama manusia akan langgeng. Dan dapat mencegah kemungkinan terjadinya konflik horizontal di masyarakat.

Ketika tetangga mendapatkan banyak nikmat dari Allah SWT, seperti membeli sepeda baru atau peralatan baru lainnya, maka tampakkanlah rasa syukur dan tidak menampakkan rasa iri. Apabila anak didik memiliki kelebihan nikmat yang diberikan Allah maka ajarkanlah mereka dan suruhlah agar memberikan sedekah, sehingga para tetangga yang belum menerima kenikmatan tersebut juga akan merasa diberkati. Sikap seperti itu dapat memperkuat hubungan bermasyarakat. 


\section{KESIMPULAN}

Dari uraian yang telah disebutkan diatas, maka dapat diambil kesimpulan:

1. Nilai-nilai Pendidikan Akhlak yang terdapat didalam Kitab Risalatul Muawwanah adalah antara lain :

a.Nilai Ilahiyah yang terdiri dari pembahasan tentang, cinta kepada Allah SWT, ridha atas taqdir Allah, memperkuat keyakinan, sikap shabar, dan memperbaiki niat.

b.Nilai Insaniyah yang terdiri dari pembahasan tentang, agar mengisi waktu dengan hal-hal yang bermanfaat, Adab saat melakukan kegiatan harian, pendidikan agar menjaga kebersihan diri, pendidikan tentang berbakti kepada orang tua, Amar makruf / memerintahkan kebaikan dan nahi munkar / melarang kejahatan, menghindari candaan yang berlebihan, memuliakan atau ta'dhim pada guru, pendidikan agsar saling tolong menolong, bersikap ramah dan menyambung silatur Rahim pada saudara, kerabat maupun tetangga,serta selalu bersimpati kepada tetangga atau orang lain.

2. Relevansi Nilai-nilai pendidikan akhlak yang ada dalam kitab Risalatul Muawwanah dengan pendidikan saat ini:

Jika dilihat dari perspektif tujuan difokuskan pada pencapaian tujuan kebaikan, hal tersebut dilandasi oleh kemampuan anak didik agar berkarakter baik dalam kehidupan sehari-hari yang memiliki landasan Alquran dan Hadits. Dan dalam hal pemberian materi pendidikan akhlak dari kitab "Risalatul Muawwanah" yang bisa menjadi referensi untuk mempelajari pendidikan agama Islam khususnya pada mata pelajaran akhlak, dan juga agar dapat diterapkan dalam kehidupan sehari-hari untuk menjadi manusia yang baik, berakhlak mulia dan berkepribadian luhur, maka Nilai pendidikan akhlak yang ada didalam kitab Risalatul Mu'awanah ini sangat erat kaitannya dengan pendidikan akhlak saat ini.

\section{DAFTAR PUSTAKA}

Al-Haddad, H. A., \& Al-Muhdlor, A. Y. (2018). Risalah Al-Mu'awanah. Surabaya: Cahaya Ilmu.

Al-Muhdhor, Y. A. (2010). Mengenal lebih dekat al-Habib Abdullah bin Alawi al-Haddad: kisah hidup, tutur kata dan tarekatnya. Surabaya: Cahaya Ilmu.

Arif, M. (2018). Konsep Pendidikan Akhlak Dalam Kitab Kitab Akhlakul Lil Banin Karya Umar Ibnu Ahmad Barjah. Tajdid: Jurnal Pemikiran Keislaman Dan Kemanusiaan, 2(2), 401-413.

Avinesa, A. (2018). Pendidikan Karakter Dalam Perspektif Habib Abdullah Bin Alwi Al-Haddad. Jurnal Pendidikan Islam, 8(1), 1-21.

Awaliyah, T., \& Nurzaman, N. (2018). Konsep Pendidikan Akhlak Menurut Sa'id Hawwa. Jurnal Penelitian Pendidikan Islam, 6(1), 23-38. https://doi.org/10.36667/jppi.v6i1.152

Azwar, S. (2015). Metode Penelitian. Yogyakarta: Pustaka Pelajar.

Bahar Agus Setiawan, Benny Prasetiya, S. R. (2019). Implementasi Tasawuf dalam Pendidikan Agama Islam: Independensi, Dialog, dan Integrasi. POTENSIA, 5(1), 64-78.

Bakker, A., \& Zubair, A. C. (2020). Metodologi Penelitian FIlsafat. Yogyakarta: Kanisius.

Devy, Habibi Muhammad dan Agustiarini, E. D. (2020). Implementation Of Children's Special Needs For Religiusity In Specific Training And Development Parks Abk. Halaqa, 4(2), 89-96. https://doi.org/10.21070/halaqa.v4i2.544

Devy, H. M. (2020). Implementasi Pendidikan Humanisme Religiusitas Dalam Pendidikan Agama Islam Di Erarevolusi Industri 4.0. Jurnal Edumaspul, 4(2), 122-131.

Hadi, S. (2015). Metodologi Riset. Yogyakarta: Pustaka Belajar. 
Herawati, E. (2020). Pendidikan Ibadah Akhlak Melalui Qiro'Ah Kitab Turats Dengan Metode Klasik Dan I'Rab. Al Qalam: Jurnal Ilmiah Keagamaan Dan Kemasyarakatan, 14(1), 59-76. https://doi.org/10.35931/aq.v14i1.312

Hidayati, N. (2019). Signifikansi Pemikiran Sayyid Abdullah Bin Alwi Al-Haddad Dalam Kitab Risalah Al-Muawanah Tentang Pendidikan Akhlak. FIKROH: Jurnal Pemikiran Dan Pendidikan Islam, 12(2), 79-100. https://doi.org/10.37812/fikroh.v12i2.53

Idi, A., \& Sahrodi, J. (2017). Moralitas Sosial dan Peranan Pendidikan Agama. Intizar, 23(1), 1. https://doi.org/10.19109/intizar.v23i1.1316

Ilyas, M. A. (2018). Ajaran Syeikh Nawawi al-Bantani Tentang Pendidikan Akhlak Anak. ARRIAYAH : Jurnal Pendidikan Dasar, 2(2), 113. https://doi.org/10.29240/jpd.v2i2.659

Juwita, D. R. (2018). Pendidikan Akhlak Anak Usia Dini Di Era Millennial. At-Tajdid : Jurnal Ilmu Tarbiyah, 7(2), 282-314.

Kanji, H. (2021). The Integration Model of the Development of Student Religious Character Education Based on Integrative Morals in Higher Education. 6(1), 149-162.

Khosiah, N. (2019). Pelaksanaan pendidikan karakter di m.i. Miftahul ulum tambakrejo tongas probolinggo. Ar-Risalah: Media Keislaman, Pendidikan Dan Hukum Islam, 17(1).

Khosiah, N. (2020). Kerjasama Orang Tua Dan Guru Dalam Pembentukan Kepribadian Anak Yang Islami Di Raudlotul Atfal. Al-Athfal : Jurnal Pendidikan Anak, 1(1), 9-20.

Moleong, L. J. (2018). Metodologi penelitian kualitatif. Bandung: PT Remaja Rosdakarya.

Muhidin, I., \& Syafri, U. A. (2016). Metode Pendidikan Akhlak Dalam Kitab Adab Al-Mufrad Karya Imam Bukhari. Misykat Al-Anwar, 1(2), 182-192.

Prasetiya, benny A. D. S. H. (2019). Bimbingan Orang Tua, Kedisiplinan dan Kosntribusinya Terhadap Pencegahan Perilaku Menyimpang. Shautut Tarbiyah, 25(2), 221-238.

Prasetiya, B. (2018). Dialektika Pendidikan Akhlak dalam Pandangan Ibnu Miskawaih dan Al-Gazāl. INTIQAD: Jurnal Agama Dan Pendidikan Islam, 10(02), 249-267.

Prasetiya, B., Safitri, M. M., \& Yulianti, A. (2019). Perilaku Religiusitas: Analisis Terhadap Konstribusi Kecerdasan Emosional Dan Spiritual. Al-Tadzkiyyah: Jurnal Pendidikan Islam, 10(2), 303-312. https://doi.org/10.24042/atjpi.v10i2.5015

Rofi, S., Prasetiya, B., \& Setiawan, B. A. (2019). Pendidikan Karakter Dengan Pendekatan Tasawuf Modern Hamka dan Transformatif Kontemporer. Intiqad, 11(2), 396-414.

Setiawan, A. (2019). Guru Berkarakter di Era Milenial (Perspektif Habib Abdullah bin Alawi AlHaddah). Al Qalam: Jurnal Ilmiah Keagamaan Dan Kemasyarakatan, 3(2), 311-328. https://doi.org/10.35931/aq.v3i2.181

Setiawan, E. (2017). Konsep Pendidikan Akhlak Anak Perspektif Imam Al Ghazali. Jurnal Kependidikan, 5(1), 43-54. https://doi.org/10.24090/jk.v5i1.1252

Sidiq, M. A. H. (2017). Telaah Pemikiran Sayyid Abdullah bin Alwy Al-Haddad Tentang Nilai-Nilai Pendidikan Akhlak dalam Kitab Risalatul Mu'awanah. Tarbiyatuna: Jurnal Pendidikan Islam, 10(2), 220-232.

Taufik, M. (2020). Strategic Role of Islamic Religious Education in Strengthening Character Education in the Era of Industrial Revolution 4.0. Jurnal Ilmiah Islam Futura, 20(1), 86. https://doi.org/10.22373/jiif.v20i1.5797 